\title{
The Influence of Teaching Styles on the Skill of Badminton Reviewed from Motor Educability
}

\author{
Ashadi Cahyadi*, Herman Subarjah, Yunyun Yudiana, Yusuf Hidayat \\ Sport Education Program Postgraduate \\ Universitas Pendidikan Indonesia \\ Bandung, Indonesia \\ *Ashadi2913@gmail.com
}

\begin{abstract}
Introduction: teaching style is considered to have an influence on badminton skills by looking at the aspects of motor educability. Purpose: This study aims to see the influence of teaching style on badminton skills in terms of high motor educability. In this study also pay attention to the influence of the teaching style between command and divergent. Method: the research used is an experimental method. Participants 30 students (Male: 20 and Female: 10) with an age range between 13-15 years. With the characteristics of having high educability motor capability. Research instruments use badminton skills tests (service, lob, dropshot and smash). Data analysis used normality test, homogeneity test and one-way ANOVA. Results and Discussion: the study showed a normality test of $0.472>0.05$. In the homogeneity test of $0.653>0.05$, it means that the variance of the data is homogeneous. While the one-way ANOVA result is FCount > FTable $(119.61>4.20)$. This study shows that teaching style influences badminton skills. Where the command teaching style shows a huge influence compared to divergent teaching styles. Conclusion: Overall the conclusions in this study are the influence of teaching style on badminton skills on high educability motors. This research can be a reference to the teacher in improving badminton skills by choosing the right teaching style and seeing the aspects of motor educability.
\end{abstract}

Keywords-command teaching style; divergent teaching style; badminton skill; motor educability

\section{INTRODUCTION}

Badminton games are one of the most popular and popular sports in Indonesia, even around the world [1]. Badminton is played using a racket and shuttlecock. Besides Badminton is a game that uses a lot of physical abilities with fast movements and hard blows done within a few seconds between long rallies [2]. The basic skills needed in badminton include how to hold the racket, standing attitude, foot movements, and hitting the shuttlecock [3]. In relation to hitting a shuttlecock one can be said to be able to play badminton if it can do multiple punches such as service, lob, drive, netting, dropshot and smash [4].

Learning movement skills is a set of internal processes that relate to training (experience) which results in relatively permanent behavioral changes in the form of skilled motion behavior [5,6]. In accordance with this definition, there are three main characteristics to understand learning movement skills. First, learning motion skills is a set of internal processes that relate to the activity of giving training (experience). The learning or experience process is a deliberately created process with the aim of mastering new knowledge and skills. Second, because of its internal nature, learning of motion skills cannot be directly observed. During the process, the brain's memory system receives a number of inputs in the form of ability and experience of motion, the input is processed, organized, and converted into patterns of motion of muscles, the process of change takes place without being able to be observed directly, unless it can only be interpreted as its existence. that occurs through motion. Third, changes in behavior that occur are relatively permanent. Students are considered learning if the changes experienced are relatively permanent, learning outcomes obtained can last relatively long. Conversely, it is not considered learning if the changes experienced are temporary and arise due to the process of physical maturity, fatigue, pain, or medication. Only through learning and experience of change that is relatively permanent will be achieved, then learning and experience become important in an effort to obtain the expected results.

To achieve these competencies, the teacher as a facilitator in learning must apply teaching styles that are in line with the objectives to be achieved. One form of facilities from the teacher to develop students' badminton playing skills in the learning process is through the application of teaching styles. In this study the teaching style applied is teaching and divergent teaching styles. teaching style is one of the most popular frameworks used to design and give instructions [7]. The teacher makes specific lesson plans and chooses those that are appropriate to the abilities and skills of their students [8]. In addition, the choice of teaching style depends largely on the goals / objectives that the teacher wants to meet with students. In previous studies teaching style was used only to see the experience of teachers and students after being given several teaching styles by Mossston [8]. In another study conducted by Mark Byra, Beth Sanchez, Tristan Walhead looked at the behavior of students and teachers in command, practice and inclusion teaching styles in terms of instruction, feedback, level of activity [9].

From some of the studies above, researchers see that teaching style can not only see the behavior or experience of students and teachers in learning by looking at several aspects. But it can also improve badminton skills by looking at the aspects of motor educability. Where research conducted by 
researchers can be said that there are still a few who do it. Other researchers only provide teaching styles without seeing the aspects of motor educability. motor educability is the ability of a person to learn or do a new movement (New Motor Skill), the high and low motor educability they have will have an effect in terms of learning or doing the new movement [10]. The researcher saw that the aspect of motor educability played an important role in the learning process provided by the teacher. Someone who has good motor educability will quickly receive lessons and be able to move quickly.

\section{METHOD}

This study aims to see the effect of teaching style on badminton skills in terms of high motor educability. The research method used is experiment. Participants 30 students (Male: 20 and Female: 10) with an age range between 13-15 years. With the characteristics of having high educability motor capability. Where the determination of motor educability is high through the Iowa-Brace test quoted from Harold Mc Cloy [11]. The Iowa-Brace test contains 21 items, of which 21 are divided into age and school levels and gender [12]. Research instruments use badminton skills tests (service, lob, dropshot and smash) [13]. Data analysis used is normality test, homogeneity test and one-way ANOVA. Normality test is used to see whether the data obtained is normally distributed. This test is also a prerequisite test section before using parametric statistics. Homogeneity test is used to see homogeneous data variants. While one way anova to seeing the difference between command and divergent teaching styles towards badminton skills.

\section{RESULTS AND DISCUSSION}

The influence of teaching style on badminton playing skills in terms of motor educability using one-way ANOVA analysis. But before testing one-way ANOVA must carry out the prerequisite test that must be passed. That is the test for normality and homogeneity. In testing the normality of techniques performed using the SPSS program, Kolmogorov Smirnov Test (Z). Data is said to be normal if the probability > 0.05. For homogeneity testing, testing techniques are carried out using the SPSS program namely Test Homogeneity of Variances. The criterion is a group of pairs compared to having a homogeneous variance. Where the probability $>0.05$. The distribution results can be seen in Table 1. Distribution of data on Normality and Table 2 of data distribution Homogeneity.

TABLE I. DISTRIBUTION NORMALITY

\begin{tabular}{|l|l|l|l|l|}
\hline No & \multicolumn{1}{|c|}{ Group } & \multicolumn{1}{c|}{$\begin{array}{c}\text { Kolmogorov } \\
\text { Smirnov }\end{array}$} & $\begin{array}{c}\text { The } \\
\text { probability }\end{array}$ & Status \\
\hline 1 & Gain Score & 0,472 & 0,05 & Normal \\
& Badminton & & & \\
& $\begin{array}{l}\text { Experiment } \\
\text { Group High }\end{array}$ & & & \\
& Motor & & & \\
& Educability & & & \\
\hline
\end{tabular}

TABLE II _ DISTRIBUTION HOMOGENEITY

\begin{tabular}{|c|c|c|c|c|}
\hline No & Group & \multicolumn{1}{c|}{$\begin{array}{c}\text { Levene } \\
\text { Statistic }\end{array}$} & Probabilities & \multicolumn{1}{|c|}{ Status } \\
\hline 1 & Gain Score & 0,653 & 0,05 & Homogen \\
& Badminton & & & \\
& Experiment & & & \\
& Group High & & & \\
& Motor & & & \\
& Educability & & $\mathrm{P}>0,05$ \\
\hline
\end{tabular}

After the prerequisite test is carried out, the next step is to test the hypothesis. Tests carried out using one-way ANOVA test. The results can be seen in table 3 the calculation of oneway ANOVA and Table 4 the average value of teaching style.

TABLE III. CALCULATION OF ONE WAY ANOVA

\begin{tabular}{|c|l|l|l|l|}
\hline No & \multicolumn{1}{|c|}{ Group } & \multicolumn{1}{|c|}{ F $_{\text {Count }}$} & \multicolumn{1}{|c|}{ F $_{\text {Table }}$} & \multicolumn{1}{c|}{ Status } \\
\hline 1 & $\begin{array}{l}\text { Badminton High } \\
\text { Motor } \\
\text { Educability }\end{array}$ & 119,61 & 4,20 & Beda \\
\hline
\end{tabular}

TABle IV. The Average Value of Teaching Style

\begin{tabular}{|l|l|l|l|}
\hline No & \multicolumn{1}{|c|}{ Value } & \multicolumn{1}{c|}{ Command } & \multicolumn{1}{c|}{ Divergent } \\
\hline 1 & Average & 9,8 & 5,1 \\
\hline
\end{tabular}

From table 3 obtained the value of F Calculate as much as 119.61 while FTable with degrees of freedom 1 (df1) and degrees of freedom 2 (df2) and significance of 0.05 obtained FTable value of 4.20. Value of FCount > FTabel $(119.61>4.20)$ means that there is a significant influence between the command style teaching group and divergence on badminton skills. From table 4 it is obtained that the average gain value of the command teaching style group is 9.8 and the divergent teaching style is 5. From the above information it can be concluded that command teaching style has more significant influence on badminton playing skills than divergent teaching styles. This can be seen in Figure 1 histogram command teaching style and divergent teaching style.

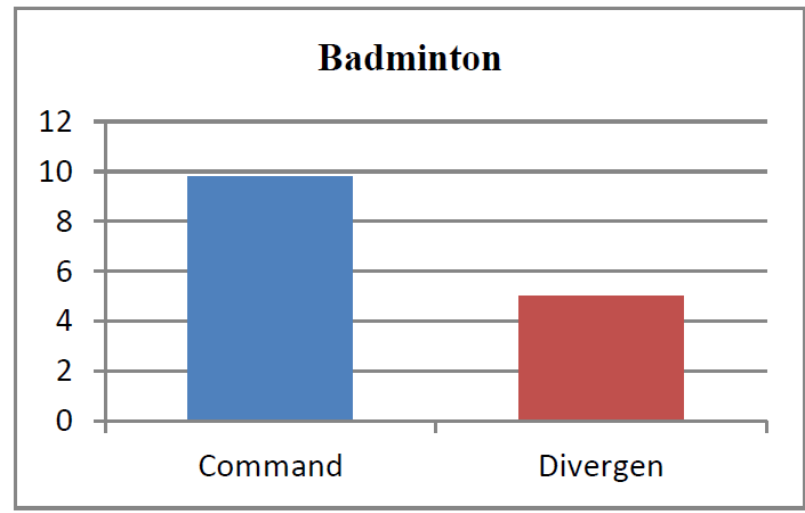

Fig. 1. Histogram command and divergen teaching style.

Judging from the results of research on the influence of teaching style on badminton skills in terms of motor 
educability aspects showed good results. This can be seen in the results of the study where the teaching style applied has an influence on badminton skills. Although the 2 teaching styles applied have significant differences. Where the command teaching style has a very significant influence compared to divergent teaching styles. Researchers consider this to be natural because the command teaching style (teacher-centered) is more organized where each learning decision is taken by the teacher both from the beginning to the end of learning. In other words, the command teaching style is also very guided. Students get direct directions from the teacher. Therefore, the opportunity for students to understand and apply the badminton skills taught will be better. Unlike the diverging (studentcentered) teaching style where not all decisions are taken by the teacher. It can be said that the divergent teaching style brings students to be independent and more creative in exploring their thoughts. The strength of students in this learning lies in their imagination abilities. Students view things from various aspects and establish relationships into a whole that is complete. So that it will bring up actions or movements in game activities that are not boring.

\section{CONCLUSION}

Based on the data obtained, the results of testing hypotheses, and discussion of research results can be summarized as follows:

- Overall there is an influence of teaching style on badminton skills on students who have high educability. Both those who use command teaching styles and divergent teaching styles.

- There are differences in teaching style of command and teaching style diverging towards badminton skills in students who have high educability. Command teaching style has more influence on badminton skills than divergent teaching styles.

\section{ACKNOWLEDGMENT}

Thank you, the writer said to Kemenristek DIKTI (Ministry of Research Technology and Higher Education) who have provided support and assistance in the form of research grants so that this research can be completed until the writing of the article and thank you also to the mentors who are very helpful in writing dissertations and scientific articles.

\section{REFERENCES}

[1] H. Subarjah, "Learning Outcomes Skills Playing Badminton Experimental Study on Students of FPOK-UPI Badminton Training," Jurnal Cakrawala Pendidikan, no. 3, 2010.

[2] R.B. Ballou, Badminton for Beginners, 2nd ed. Colorado: Morton Publishing Co, 1998.

[3] T. Grice, Badminton for the College Student, 4th ed. Boston, Massachusetts: American Press, 1994

[4] C. Wattanasin, Badminton a Simple Way, Badminton Booklet. London: The IBF, 2000.

[5] R.A. Schmidt, Motor Learning \& Performance. Illinois: Human Kinetics Books, 1991.

[6] M.G. Fischman and J.B. Oxendine, Motor Skill Learning for Effective Coaching and Performance. In Williams, J.M. Applied Sport Psychology, Personal Growth to Peak, 1993

[7] Performance, London: Mayfield Publishing Company.

[8] M. Mosston and S. Ashworth, Teaching physical education. (5th ed). New York, NY: Benjamin Cummings, 2002

[9] Byra, M, Sanchez, B, Walhead, T. 2013. Behaviors of students and teachers in the command, practice, and inclusion styles of teaching: Instruction, feedback, and activity level. USA: European Physical Education Review 2014, Vol. 20(1) 3-19, Published by SAGE.

[10] Nurhasan, Test and Measurement Of Sport. Bandung: Depdikbud FPOK IKIP Bandung, 1998.

[11] H.M. Cloy, Test and Measurment In Health and Physical Education. New York:APLETON-CENTURY-CROFTS,Inc, 1954.

[12] Jhonson, Practical Measurement For Evaluation in Physical Education 4rd. Macmillan Pubhlishing Company, 1984.

[13] Y. Hidayat, "The Effect of Goal Setting and Mental Imagery Intervention on Badminton Learning Achievement Motor Skill at 10-12 Years Old: The Context of Indonesia," International Journal for Educational Studies, vol. 3, no. 2, 2011. 